\title{
El Abencerraje como problema heroico: una lectura según modelos homéricos
}

\author{
José Carlos Terradas \\ Florida International University
}

\section{RESUMEN}

A pesar de las profundas relaciones épicas y mitológicas que presenta el Abencerraje y el conocimiento en esta materia del presunto autor, Antonio de Villegas, aún carecemos de estudios que conecten la obra con los modelos homéricos. Este artículo representa un esfuerzo por ejemplificar cómo la búsqueda de la belleza que en un principio se entendía como recuperación de la amada, se transforma en una búsqueda ética que propicia la ascesis heroica. Haremos una revisión crítica acerca de Nárvaez y Abindarráez, de sus supuestas diferencias, del compromiso de ambos con el logro de la admiración pública, de su alejamiento de los placeres sensuales para consumar un paradigma caballeresco y guerrero compartido. Finalmente, nos detendremos en la cosmología que presenta la obra con el objeto de explicar un sistema religioso opresivo que se disfraza de cristianismo, pero que en el fondo contiene mucho del concepto griego de la envidia de los dioses.

Pablaras clave: Abencerraje, heroísmo, Homero, épica.

\section{The Abencerraje as an heroic problem: a reading according homeric patterns}

\begin{abstract}
Despite the deep epic and mythological relations that the Abencerraje presents and the knowledge in this area of the alleged author, Antonio de Villegas, we still lack of studies connecting the work with Homeric patterns. This paper represents an effort to illustrate how the quest for beauty that initially was understood as the retrieving of the beloved lady, ultimately becomes an ethical quest that favors heroic asceticism. We will critically review about the characters of Narváez and Abindarráez, their presumed differences, their commitment to attain public esteem, their detachment from sensual pleasures in order to complete a chivalrous and warlike paradigm. Finally, we stop at the cosmology that the work presents in order to explain an oppressive religious system masquerading as Christianity, but that basically contains much of the Greek concept of the envy of the gods.
\end{abstract}

Key words: Abencerraje, heroism, Homer, epic. 


\section{INTRODUCCIÓN}

A pesar de que el Abencerraje, como cualquier obra del Renacimiento, se sitúa en una época deudora de la antigüedad clásica, y de que contiene elementos que en sí mismos llaman a un análisis comparativo sobre sus reminiscencias épicas, carecemos de estudios que establezcan conexiones profundas con otros discursos heroicos o mitológicos. Los investigadores han tocado el tema someramente desde diferentes puntos de vista. Valiosas apreciaciones han sido hechas por Deferrari ${ }^{1}$, López Estrada ${ }^{2}$, Bataillon ${ }^{3}$, Casalduero ${ }^{4}$ sobre los relatos clásicos y, en especial, sobre la historia de Sálmacis y Hermafrodito, proveniente del libro IV de la Metamorfosis de Ovidio, y conocida para la fecha gracias a la adaptación romanceada que arregló el humanista Jorge de Bustamante ${ }^{5}$. Desde una perspectiva histórica, el estudio de este mito es lo que le sirve a Bataillon para ofrecer pistas sobre la fecha de escritura de las diferentes versiones del Abencerraje y la prelación intrínseca que las versiones de Villegas y la Chrónica deben seguiró. López Estrada tan sólo le dedica unas palabras al relato clásico para sugerir, ya en el terreno de la significación, que el deseo de Abindarráez de convertirse en Troco estimularía, siguiendo la anécdota original, el nacimiento de amor en la muchacha ${ }^{7}$. Casalduero, por su parte, aumenta el repertorio clásico con la referencia simbólica a la historia de Píramo y Tisbe, la cual se proyecta como ambiente de

\footnotetext{
${ }^{1}$ Deferrari, Harry A. «Trocho in El Abencerraje». Modern Languages Notes. 1927, vol. 42, n. ${ }^{\circ} 8$, pp. 529-530.

${ }^{2}$ López Estrada, Francisco. «Introducción», en El Abencerraje (Novela y romancero). Madrid: Cátedra, 1980, p. 116.

${ }^{3}$ Bataillon, Marcel. Varia lección de clásicos españoles. Pérez Riesco, José (trad.). Madrid: Gredos, 1964. pp. 31-38.

${ }^{4}$ Casalduero, Joaquín Gimeno. «El Abencerraje y la hermosa Jarifa: composición y significado». Nueva Revista de Filología Hispánica. 1972, vol. XXI, n. ${ }^{1}$ 1, pp. 9-11.

${ }^{5}$ Bataillon, Marcel, op. cit., 34.

${ }^{6}$ Deferrari propone que en la conocida escena de la huerta de los jazmines, donde Abindarráez insinúa un amor más que fraternal a Jarifa, 'Troco' debe leerse 'tronco', gracias al carácter casi ininteligible de la grafía 'Troco' en los textos de Villegas y la Chrónica, y principalmente debido a ciertos versos de un romance de Juan de Timoneda: «Quién fuera tronco / para estar junto a la ninfa». Deferrari, Harry A., op. cit., 530. De esta manera, la palabra exacta en un supuesto texto original, hoy perdido, fuese 'trôco', y la omisión de la tilde por error en las obras posteriores la hubiese convertido en nombre propio. La prueba fundamental de Bataillon para oponerse a esta teoría es que otros autores del Renacimiento y posteriores aluden a Hermafrodito bajo en nombre de Troco sin que su grafía pueda ser confundida o malinterpretada, lo que no deja dudas acerca de la validez del personaje mitológico, pero no esclarece del todo el postulado central, a saber, que el Inventario precede a la Chrónica. Por otra parte, es válida la ironía del investigador cuando descree que Abindarráez se conforme con ser un simple tronco. Bataillon, Marcel, op. cit., 33.

${ }^{7}$ López Estrada, Francisco, op. cit., 117.
} 
fondo que sustentaría la conformidad amorosa de los personajes desde muy temprana edad. Al mito de Sálmacis y Hermafrodito agrega el de Narciso, contenido asimismo en el libro III de la Metamorfosis, para explicar los deseos imperativos de Abindarráez de fundirse con Jarifa como consecuencia de su pasión irrefrenable ${ }^{8}$, lectura que también comparte López Estrada. Vale la pena mencionar que tanto este último ${ }^{9}$ como Casalduero ${ }^{10}$ dedican buenas páginas de sus estudios al tratamiento de la virtud alcanzada por los personajes principales, dando paso a una posible conexión de la obra con la materia heroica, otra forma de abordar el legado clásico, que hasta ahora sólo pocos investigadores han seguido y cuyos trabajos han arrojado resultados radicalmente opuestos.

Una de las investigaciones más valiosas que poseemos sobre el asunto de lo épico es «Power, Discourse, and Metaphor in the Abencerraje» de Israel Burshatin, aunque su propósito no sea precisamente el estudio minucioso de lo heroico sino cómo se erige un modelo de dominación de acuerdo con el acervo histórico y artístico en el que — según el autor- se inserta la obra. Burshatin nos recuerda la animadversión real que existió entre los bandos cristianos y moros que algunos investigadores han tratado de soslayar en el intento de ver en la novela un panfleto que llama a la concordia. Para sustentar esta línea de argumentación nos devela cómo Rodrigo de Narváez, paradigma del caballero cristiano, descuella sobre sus adversarios moros, tiene el poder indiscutible de retener o liberar a Abindarráez, es equiparado en ciertas ocasiones a la virtud o incluso a la fortuna y da órdenes explícitas al rey de Granada a través de la carta que le envía. ${ }^{11}$ La única objeción de peso que se podría hacer al valioso artículo de Burshatin es que no trata lo épico en un sentido amplio, parece reducirlo a confrontaciones bélicas entre religiones antagónicas. Por eso no puede entender que una de las bases de los discursos heroicos sea el reconocimiento del enemigo como agente de poder, ya bien en relación con su fuerza o con su número, capaz de representar un peligro cierto y, al mismo tiempo, posiblemente compartir un ideal común: la ganan-

\footnotetext{
${ }^{8}$ Casalduero, Joaquín, op. cit., 9-10.

${ }^{9}$ López Estrada, Francisco, op. cit., 24-33; 43-47; 118.

${ }^{10}$ Casalduero, Joaquín, op. cit., 14-22.

${ }^{11}$ Burshatin, Israel. «Power, Discourse, and Metaphor in the Abencerraje», Modern Languages Notes. 1984, vol. 99, n. ${ }^{\circ}$ 2, pp. 202-210. Burshatin no menciona todo el párrafo concerniente a las órdenes, que más bien parece un pacto entre dirigentes de un mismo nivel: «Suplico a tu real alteza que el remedio de estos tristes se reparta entre ti y mí. Yo les perdonaré el rescate y les soltaré graciosamente; sólo harás tú que el padre de ella los perdone y resciba en su gracia». No olvidemos que Narváez en el Inventario desecha el oro y acepta como recompensa los caballos y las armas, y esto con el objeto de «defender de sus enemigos» a Abindarráez, poniéndose a sus órdenes, aunque la promesa suene mucho a fórmula tópica de cortesía. El Abencerraje (Novela y romancero). López Estrada, Francisco (ed.). Madrid: Cátedra, 1980. pp. 134; 137: 210.
} 
cia de honor. El no reconocimiento del contrario en su justa medida crea un género muy diferente, la tragedia, y provoca además la deformación propia.

El artículo de Ricardo Krauel, «El esquema heroico de la historia de Abindarráez», constituye otro esfuerzo por relacionar la materia épica con el Abencerraje. En su intento por definir al personaje de Abindarráez, el autor se vale de las teorías de Northrop Frye y de Joseph Campbell, las cuales proponen tres estadios en la formación del héroe que se podrían resumir a grandes rasgos de la siguiente manera: la separación de la comunidad, el enfrentamiento con la muerte, y el regreso. Krauel nos lleva de la mano por las dos primeras etapas que, al parecer, se ajustan perfectamente al moro, según el modelo propuesto por los teóricos mencionados. Sin embargo, el hecho de que Abindarráez no regrese victorioso y reconocido a Granada le vale a Krauel para afirmar que el arquetipo heroico no se ha cumplido a cabalidad ${ }^{12}$.

También contamos con el trabajo de Kathleen Bollard, «Re-reading heroism in El Abencerraje», cuyo objetivo es demostrar los disímiles tratamientos que reciben los personajes principales. Mientras Narváez es presentado por cada una de las versiones como héroe épico, con todos los atributos de masculinidad que esto implica, y su imagen no difiere sustancialmente de un texto a otro; Abindarráez, por el contrario, es construido como héroe propio de las baladas, amartelado, afectado, subyugado por lo emocional, una imagen que varía de acuerdo con la versión que se estudie y que revela las relaciones ambivalentes que a través de los años España sostuvo con los moros. La amenaza latente que suponía el avance del mundo musulmán se transforma, gracias a la literatura, en personajes que no acceden completamente a la masculinidad y que, por lo tanto, dejan de representar, al menos en el arte, un peligro cierto ${ }^{13}$.

${ }^{12}$ Krauel, Ricardo. «El esquema heroico de la historia de Abindarráez», Romance Notes. 1996, vol. 37, n. ${ }^{\circ} 1$, pp. 41-45. Krauel parte desde un punto de vista que no parece el más adecuado para sus propósitos. Atribuye la combinación «dañado subjecto» del prólogo del Inventario, cuya interpretación ha sido tan discutida, directamente a Abindarráez y, sin embargo, simultáneamente nos lo propone como figura heroica. Además plantea que la misión del Abencerraje es restaurar la honra familiar, cuando esta tarea no parece ser ni la principal función del personaje ni la de la novela, si bien es cierto que a través de los hechos de Abindarráez es posible mirar con diferentes ojos la supuesta conspiración de la encumbrada familia mora en tanto los hechos tienen que ver con el linaje. A fin de cuentas, algo es seguro, la deshonra de los Abencerrajes no tocó, según el relato, a la familia directa del protagonista, lo que hace difícil la afirmación de que el moro tenga como propósito explícito limpiar el apellido. Lo mismo ocurre con el regreso al sitio de origen, ya que se podría argumentar que no es Granada sino Cártama, adonde fue enviado inmediatamente después de su nacimiento. Por otra parte, héroes como Aquiles, Áyax, Patroclo, Eneas, Roldán, el Cid, nunca regresan a sus lugares originales y no por ello la heroicidad de tan sobresalientes guerreros es puesta en tela de juicio.

${ }^{13}$ Bollard, Kathleen. «Re-reading heroism in El Abencerraje», Bulletin of Spanish Studies. 2003, vol. LXXX, n. ${ }^{\circ}$, pp. 298-299. 
Llama la atención que hasta ahora ninguno de los críticos que ha estudiado el tema heroico o mitológico se haya detenido en el análisis de la épica clásica o al menos en lo épico como asunto arquetípico. Han resumido el tema hasta su mínima expresión, asimilándolo a lo literalmente guerrero, la Reconquista, las escaramuzas, las batallas, las armas, la destreza física de los protagonistas, desconociendo la posibilidad de la épica en tanto forjadora y moldeadora de hombres. La escasez de investigaciones se acentúa cuando ojeamos las referencias mitológicas de las que hemos hecho mención, cuando a éstas agregamos el mito del juicio de Paris, sólo tratado por Casalduero brevemen$\mathrm{te}^{14}$; cuando pasamos revista a las actuaciones de los personajes principales y consideramos sus maneras caballerescas; cuando nos asomamos a la famosa escena de la fuente de los jazmines y notamos no sólo el concurso de El Cortesano de Castiglione sino también reminiscencias claras a El Banquete de Platón o a La República; cuando incluso en el Inventario se hace alusión a los «inmortales» de Darío que relata Heródoto en su Historia. ${ }^{15}$ Más aún en el entendido de que el probable autor original, Antonio de Villegas, incluyó en su obra junto a la Historia del Abencerraje y la hermosa Xarifa, la Oración de la Reina Dido á Eneas, la Historia de Píramo y Tysbe, el Llanto de Pílades por la muerte de Orestes, y además la Contienda y disputa entre Aiax Telamón y Ulises, trabajos que no dejan dudas acerca del manejo que al menos dicho escritor poseía sobre anécdotas clásicas ${ }^{16}$.

\section{Paradigmas heroicos EN EL ABENCERRAJE}

La obra se inicia con un lugar común de la épica que no podría pasar inadvertido para los conocedores de la Ilíada. Si bien es cierto que el capitán Narváez se ha hecho un nombre gracias a sus proezas contra los moros, lo que ha redundado en el reconocimiento del rey y la dirigencia de las alcaldías de Antequera y Álora, él y sus hidalgos han permanecido ociosos durante muchos días, sin lograr ningún mérito que les acreciente la fama. Al recuento de las hazañas anteriores de Narváez, la obra opone la inacción presente y la

\footnotetext{
${ }^{14}$ Casalduero, Joaquín, op. cit., 11.

${ }^{15}$ Heródoto. Los nueve libros de la historia. Lida de Malkiel, María Rosa (ed.). Barcelona: Océano, 1999. p. 83. La referencia sólo se encuentra en la versión de Villegas. La Diana únicamente menciona que poseía «cincuenta hidalgos escogidos a sueldo del rey». Montemayor, Jorge de. Los siete libros de la Diana. López Estrada, Francisco (ed.). $2^{\text {a }}$ ed. Madrid: Espasa Calpe, 1954, p. 204. Y el autor de la Chrónica hace alusión a un rey indeterminado. Rumeau, Aristide. «L'Abencérage. Un texte retrouvé», Bulletin Hispanique. 1957, vol. 59 , p. 377.

${ }^{16}$ El valioso artículo de Corominas, «Antonio de Villegas y Jerónimo de Millis: acuerdos y desacuerdos en torno a la segunda edición del Inventario», aclara los contenidos nuevos de la edición de 1577, la rentabilidad de ellos, la innovación tecnológica, los costos, etc.
} 
premura opresora de volver a salir y evitar la pasividad vergonzosa, dándonos a entender desde un primer momento que la condición heroica no trata de la conformidad burguesa o de los réditos que un evento en particular produce. Quizá la Chrónica es la versión que mejor lo ilustra cuando hace decir a Narváez:

que ninguna cosa desprecian ${ }^{17}$ tanto | los coraçones y animos de los hombres | como el continuo ejercicio de las armas | porque con la experiencia se hacen cap- $\mid$ tos y auisados y aprenden a tener vn mis- $\mid$ mo rostro a la fortuna prospera como ad- | uersa : de suerte que en las aduersidades el | animo se enflaquesce : ni decae : ni en las $\mid$ prosperidades se ensoberuesce ni eleua. [...] Digo esto porque | me paresce que han pasado muchos dias | en que no auemos hecho cosa que demos mu- $\mid$ estra de nuestras personas y nuestra fa- $\mid$ ma y honrra se acreciente $^{18}$.

Así la obra nos inserta desde un primer momento en una forma de vida extrema que privilegia siempre el futuro, lo que se podrá lograr, y en este sentido tiene la urgencia de sustentarse a sí misma a través de la igualación o superación del pasado. El ejemplo de los héroes griegos es paradigmático, en especial el de Aquiles porque, a pesar de que ha conquistado doce ciudades previamente ${ }^{19}$, la Ilíada rechaza recapitular lo antiguo y apuesta por sacar al héroe de su apatía ignominiosa y por la generación de nuevas proezas, entre las que destaca no sólo el famoso combate contra Héctor sino también la necesidad de reconciliarse con Agamenón. Si la primera es singular por lo llamativo de la hazaña física, la otra no deja de tener importancia en la medida en que resuelve el problema griego intestino y evita que Aquiles regrese con los poderosos mirmidones a su natal Ftía, apuntando así al mismo centro del cometido épico, la educación del héroe, y llamando la atención sobre cómo el problema del rapto de Helena a manos de Paris se refleja en la usurpación de Briseida por parte de Agamenón en la asamblea del canto I. De la misma manera que el ejercicio de las armas es importante en este tipo de relatos, el manejo de la palabra, léase la negociación, la contención de las pasiones, la superación de lo emocional, no le va a la zaga. Buena parte de la obra se debe precisamente al problema que se produce en la asamblea inicial, fuera del campo de batalla y de la acción guerrera. De allí que el mentor de Aquiles en la Ilíada, Fénix, intente combatir la obstinación del héroe frente a las tentativas de entendimiento del Atrida con el recuerdo de la educación que de él ha recibido:

\footnotetext{
${ }^{17}$ La versión de Villegas coloca 'despierta' en lugar de 'desprecia', lo que tiene lógica capital, pues le da coherencia a todo el párrafo. El Abencerraje, op. cit., 106.

${ }^{18}$ Rumeau, Aristide, op. cit., 378.

${ }^{19}$ Homero. Ilíada Odisea. García Gual, Carlos (ed.); Emilio Crespo Güemes y José Manuel Pabón (trad.). Madrid: Espasa Calpe, 1999. IX, 328.
} 


\begin{abstract}
Soy la escolta que te dio Peleo, el anciano conductor de carros, aquel día en que te envió de Ftía ante Agamenón, cuando sólo eras un niño ignorante aún del combate, que a todos iguala, y de las asambleas, donde los hombres se hacen sobresalientes. Por eso me despachó contigo, para que te enseñara todo eso, a ser decidor de palabras y autor de hazañas ${ }^{20}$.
\end{abstract}

El viejo ayo recuerda el paradigma que deben seguir los héroes, el cual resulta del engranaje adecuado entre esfuerzo y discurso, en tanto mantienen una relación intrínseca y complementaria, y no son modelos aislados. La Ilíada quizá no sea el mejor ejemplo de cómo alcanzar el paradigma planteado por Fénix, dado su carácter preponderantemente guerrero, y porque la resolución del problema intestino de los griegos (la concordia entre Aquiles y Agamenón) se resuelve tardíamente en la obra y, además, porque los héroes no están interesados en volver a una vida pacífica sino a entregar todo en la batalla. Sin embargo, la mentalidad griega logró construir la Odisea sobre la base de un personaje tan genial como ambiguo, Ulises, paradigma del héroe capaz de contenerse a sí mismo, guerrero que tiene que ser esforzado para llegar a ser burgués, monarca dispuesto a bajar a la altura de pordiosero para crear matrimonio, reino, orden. Uno de los pocos cuya transformación psicológica le permitió no sólo volver a la patria original, Ítaca, sino destronar a los pretendientes que la azotaban y, al mismo tiempo, negociar de alguna manera la paz con el bando opuesto, como se relata al final del Canto XXIV de la Odisea. No en balde la divinidad protectora que siempre lo acompaña es Atenea, diosa de ímpetu guerrero que a la vez connota ideas de moderación, sensatez, inteligencia, estrategia militar, acuerdo, límite, experta además en las formas que se deben guardar en los ámbitos más señoriales y cortesanos. La idoneidad de este personaje no pasó inadvertida para Villegas, si consideramos la Cuestión y Disputa entre Áyax Telamón y Ulises sobre las armas de Aquiles, contenida en el Inventario de 1577, donde el autor, siguiendo a Homero, al libro trezeno de las Transformaciones y posiblemente al Áyax de Sófocles, nos entrega un ejemplo de guerrero que no sólo es valioso en el combate:

De mi seso y de mis manos
no doy testimonios ciegos;
de mi elocuencia, a los griegos,
de mi esfuerzo a los troyanos ${ }^{21}$.

A lo largo de la narración del Abencerraje encontramos varios momentos en los que se describe el paradigma de caballero que la obra pretende alcan-

\footnotetext{
${ }^{20}$ Homero, op. cit., IX, 438-43.

${ }^{21}$ Villegas, Antonio de. Inventario. Madrid: Colección Joyas bibliográficas, 13, 1955, p. 124 .
} 
zar o recuperar, como enseguida veremos. Lo que llama la atención es que, no obstante las diferencias culturales y religiosas de los protagonistas, éste es en esencia siempre el mismo, como si la obra nos hablara de un asunto arquetípico que no repara en atavismos singulares. La descripción rayana en la utopía de la familia de los Abencerrajes referida por Abindarráez se enmarca en una geografía y época particular, pero no por esto parece diferir de la abstracción de héroe expuesta por el viejo Fénix, y encarnada de manera casi apoteósica en el Ulises de la Odisea. Todas las versiones de la obra se regodean en la descripción de esta ilustre estirpe granadina, históricamente asociada a los cristianos ${ }^{22}$, pero mientras el Inventario condensa en pocas líneas la alabanza, la Chrónica y la Diana se explayan un poco más, como podemos observar en las líneas de esta última:

huvo en Granada un linaje de cavalleros llamados Abencerrajes; sus hechos y sus personas ansí en esfuerço para la guerra, como en prudencia para la paz, y govierno de nuestra república eran el espejo de aquel Reyno. Los viejos eran del consejo del Rey, los moços exercitavan sus personas en actos de cavallería sirviendo a las damas y mostrando en sí la gentileza y valor de sus personas. [...] nunca cometieron cosa en la guerra ni en el consejo, que la experiencia no correspondiese a lo que dellos se esperava; en tanto grado era loado su valentía, liberalidad y gentileza, que se traya por ejemplo, no aver Abencerraje covarde, escasso, ni de mala disposición. Eran maestros en los trajes, de las invenciones, la cortesía y servicio de las damas [...] nunca Abencerraje sirvió a dama de quien no fuesse favorescido, ni dama se tuvo por digna de este nombre que tuviesse Abencerraje por servidor ${ }^{23}$.

Si bien llama la atención las maneras extremadamente cortesanas de la familia, asimismo lo hace una marcada tendencia por ligar de forma indisoluble los asuntos que tienen que ver tanto con la paz como con la guerra, lo que forma una dualidad compacta, una correspondencia proporcional. No causa extrañeza el acento del autor en los cortejos palaciegos de las últimas líneas ya que vienen sustentadas por la alta capacidad en materia netamente bélica o gubernamental de la famosa prosapia. La crítica no ha reparado en que la misma descripción que se usa para los Abencerrajes, aunque de una forma más sobria y menos detallada, es la que sirve para presentar al capitán español en el inicio de la obra. La versión del Inventario nos dice que hubo «un caballero que se llamó Rodrigo de Narváez, notable en virtud y hechos de armas» ${ }^{24}$. La Chrónica contiene exactamente el mismo mensaje, difiriendo de manera superflua en la ortografía ('cauallero', 'Narbaez') y en la pluralización de virtud, dado que el resto del contenido es igual ${ }^{25}$. Ambas perspectivas, por

${ }^{22}$ Fosalba, Eugenia. «Sobre la verdad de los Abencerrajes», Boletín de la Real Academia de Buenas Letras de Barcelona. 2002, vol. 48, pp. 315; 328-29.

${ }^{23}$ Montemayor, Jorge, op. cit., 208.

${ }^{24}$ El Abencerraje, op. cit., 104.

${ }^{25}$ Rumeau, Aristide, op. cit., 377. 
supuesto, enfatizan las conquistas militares. La versión de la Diana es un poco más extensa y específica en la pintura del héroe cristiano:

huvo un cavallero en España llamado Rodrigo de Narváez: cuya virtud y esfuerço fue tan grande, que ansí en la guerra como en la paz alcanço nombre muy principal entre todos los de su tiempo, y señaladamente se mostró quando el dicho señor infante (Fernando, rey de Aragón) ganó de poder de los moros la ciudad de Antequera: dando a entender en muchas empresas de armas que en esta guerra succedieron, un ánimo muy entero, un corazón invencible, y una liberalidad, mediante la qual el buen capitán no sólo es estimado de su gente: mas aun la agena haze suya ${ }^{26}$.

Aunque el pasaje carece de la sensualidad propia de los Abencerrajes que se mostró un poco más arriba, sí es útil para engranar los espacios de la paz con los espacios de la guerra y hacer de ellos entidades inseparables a pesar de sus diferencias. Narváez se encarga de equilibrar la virtud y el esfuerzo, de sopesar los hechos de armas con la conducta fuera de la batalla, de vencer tanto por la fuerza como por el carisma. La preponderancia recae en un principio en el ámbito bélico, como ya han señalado algunos críticos ${ }^{27}$, pero no es tan pronunciada como para descartar otros ámbitos, ni siquiera la sensualidad de Narváez, de la cual hablaremos más adelante. Y, en todo caso, no estaríamos lejos de la verdad si decimos que la obra, al mismo tiempo que revisa la actividad guerrera del capitán español, se deleita también en acciones que no se realizan precisamente en el campo de batalla y que, sin embargo, son consideradas por los propios autores como las de más alabanza. El relato nos presenta desde el inicio a un héroe encumbrado por su participación en exitosas campañas militares, y aunque asistiremos a una escaramuza menor, origen de toda la trama, el máximo triunfo del capitán parece desprenderse de su comportamiento en la administración de la paz, a juzgar por el decir de los mismos protagonistas y la evidencia que presenta la novela como un todo que prefiere narrar la liberalidad de Narváez antes que un nuevo conflicto armado ${ }^{28}$. En la versión de Villegas, Abindarráez cataloga el acto de su adversario cristiano de otorgarle la libertad como «la mayor gentileza de corazón que nunca hombre hizo» ${ }^{29}$, lo que no deja de repetirse puntualmente en las demás obras con ligeras modificaciones ${ }^{30}$. Y el mismo alcalde de Álora, en la carta final del Inventario, afirma que nunca se le había ofrecido «empresa tan generosa ni tan digna de capitán español», sopesando su munificencia para con el moro como digna de presentarse a las generaciones futuras. El

\footnotetext{
${ }^{26}$ Montemayor, Jorge, op. cit., 204.

${ }^{27}$ Bollard, Kathleen, op. cit., 300.

${ }^{28}$ Burshatin, Israel, op. cit., 202. Avilés, Luis F. «Los suspiros del Abencerraje», Hispanic Review. 2003, vol. 71, n. ${ }^{\circ}$, p. 457.

${ }^{29}$ El Abencerraje, op. cit., 123.

${ }^{30}$ Rumeau, Aristide, op. cit., 388; Montemayor, Jorge, op. cit., 215.
} 
desprendimiento de este personaje es lo que hace decir a Jarifa para cerrar la novela de Villegas que «quien pensare vencer a Rodrigo de Narváez de armas y cortesía, pensará mal» ${ }^{31}$, un postulado que vuelve a reunir la materia bélica con la vida cotidiana en un todo engranado.

\section{PALABRA, ACCIÓN Y MATERIALIZACIÓN DEL HEROÍSMO}

La Ilíada y la Odisea pudieran leerse como poemas que tratan de poner el mundo en orden en la medida en que pretenden crear una relación de continuidad entre la paz y la guerra. A pesar de que los esforzados (Aquiles - Ulises) debieran recibir o poseer el justo reconocimiento por sus hazañas y su epifanía (el trofeo), y merecer los privilegios de la paz que se han ganado en el campo de batalla, otros (Agamenón, Paris - los pretendientes) son los que los ostentan. A esa relación por lo general aluden las arengas épicas, en las cuales los líderes increpan en pleno combate a los guerreros con el propósito de que respalden con el brazo los privilegios que obtienen en los festines:

- Idomeneo! Te aprecio entre los dánaos, de veloces potros,
tanto en el combate y para cualquier empresa,
como en el banquete, cuando el rutilante vino honorífico
los adalides de los argivos mezclan en la crátera.
Si es verdad que los demás aqueos, de melenuda cabellera,
beben su ración, tu copa sin embargo siempre se alza llena,
como la mía, para beber siempre que el ánimo lo apetezca.
Ve al combate y pórtate como desde antiguo te jactas de $\operatorname{ser}^{32}$.

El discurso épico le da una nueva significación a la palabra, transformándola en un hecho visible, que necesita comprobarse, que no es cierta hasta que se transmuta en acción. Muchos ejemplos provenientes de las obras clásicas griegas podrían ser citados, pero quizá el más ilustrativo no lo encontremos allí sino en el propio Poema de Mio Cid, cuando Pedro Bermúdez cataloga a Fernando de Carrión como «una lengua sin manos» ${ }^{33}$, despojándolo por sus actos vergonzosos de cualquier altura épica y denunciando precisamente la contradicción entre sus palabras y sus hechos. La escena vuelve a repetirse cuando, en concordancia precisa, Martín Antonílez llama a Diego de Carrión casi de la misma manera: «boca sin verdad» ${ }^{34}$.

La materialización de la palabra está relacionada con el asunto heroico en el sentido de que hace visible la valía, descubre la calidad de los personajes.

\footnotetext{
${ }^{31}$ El Abencerraje, op. cit., 137.

${ }^{32}$ Homero, op. cit., IV, 257-264.

${ }^{33}$ Poema de Mio Cid. Lacarra Lanz, Eukene (ed.). Barcelona: Área, 2002. 3328.

${ }^{34}$ Ibídem, 3362.
} 
De allí que el heroísmo sea una cosa pública. El héroe es tal en la medida en que es reconocido por sus pares; su propia imagen es buscada en la apreciación que los otros tienen sobre él mismo. La interioridad psicológica es mínima o, al menos, bastante difusa, y de hecho es un reflejo de la valoración popular que recibe de la comunidad ${ }^{35}$. No es descabellado afirmar que la misma persona heroica es objeto de exteriorización junto con todos los aparejos que su naturaleza requiere. Así, no es raro encontrar cosas materiales que sólo pueden pertenecer a héroes en particular: el infrangible escudo de Áyax, que, según Sófocles ${ }^{36}$, el propio héroe siente como imperativo dejar en herencia a su hijo; el arco de Ulises, que únicamente pudo ser tensado por él mismo en el canto XXI de la Odisea; o las armas de Aquiles, hechas por el propio Hefestos, y a las cuales se les dedica casi todo el canto XVIII de la Ilíada, por nombrar unas pocas. Carece de sorpresa, entonces, que en estos discursos hasta la misma apariencia física de los héroes sea valorada como metáfora que cobra significado en la medida que es reflejo de las hazañas, del poderío o, en el caso de Ulises, de una extraña combinación de proezas y facundia. Es lo que se desprende de la conversación entre Helena y Príamo cuando observan desde las murallas a los distintos jefes griegos:

Príamo, alzando la voz, llamó a Helena: [...]

«Ven aquí, hija querida [...]

¿Quién es ese guerrero aqueo noble y alto?

Cierto que hay otros más altos [...]

pero hasta ahora no he visto en mis ojos a nadie más bello

ni tan majestuoso. Lo digo porque parece un rey».

Respondiole Helena [...]

«Ése es el Atrida Agamenón, señor de anchos dominios» [...]

«Ea, dime también éste, hija querida, quién es.

Es más bajo que el Atrida Agamenón, que le saca la cabeza,

pero se le ve más ancho de hombros y de pecho. [...]

«Ese otro es el Laertíada, el muy ingenioso Ulises [...]

Es experto en toda clase de engaños y sagaces artimañas».

«¿Y quién es este otro aqueo, noble y alto,

cuya cabeza y anchos hombros sobresalen entre los argivos?» [...]

«Ése es el monstruoso Ayante, baluarte de los aqueos ${ }^{37}$.

La Ilíada también incluye dos personajes, Tersites y Dolón, que no cumplen con los estándares de belleza corporal que dejan perplejo a Príamo, y que incluso mueven a risa por lo maltrecho y desproporcionado de sus talantes. La misma obra se encarga de desacreditarlos y eliminarlos del canon desea-

\footnotetext{
${ }^{35}$ Dodds, E.R. Los griegos y lo irracional. Araujo, María (trad.). Madrid: Alianza, 1999. p. 30

${ }^{36}$ Sófocles. Las siete tragedias. Garibay, Ángel (ed.). 13ª ed. México, D. F.: Editorial Porrúa, 1976, p. 17.

${ }^{37}$ Homero, op. cit., III, 161-229.
} 
do, no precisamente por la deformidad física en sí sino porque ésta es reflejo inequívoco de una conducta cobarde. Tersites insulta a los máximos líderes griegos en la asamblea del canto II y, más aún, propone la retirada definitiva de las tropas, cosa que no va a ser tolerada por el código ético del poema. Dolón pretende lograr hazañas que sobrepasan sus propias capacidades, impulsado, más que por la gloria de los actos, por la ingente recompensa que le es ofrecida ${ }^{38}$. La belleza de Paris, por su parte, también es criticada porque las cualidades que se le atribuyen (seductor, lujurioso, mujeriego) no son épicas, no generan hazañas gloriosas y contravienen la relación de proporcionalidad entre el acto heroico y el reconocimiento público, como denuncia Héctor en el canto III: «A carcajadas seguro que ríen los aqueos [...] / que creían que eras paladín y campeón, porque es bella / tu apariencia; pero en tus mientes no hay fuerza ni coraje ${ }^{39}$.

Estas nociones de la épica clásica no son para nada extrañas a otras narraciones heroicas y se han conservado casi intactas en textos como el Amadís de Gaula, por ejemplo, donde se menciona machaconamente la belleza de los protagonistas principales, al tiempo que se alaban sus hazañas. De hecho, en la breve descripción de un personaje como el magnate Barsinán, el autor sólo cree prudente acotar que era «más grande por su estado que por sus virtudes $»^{40}$, pincelada que luego se comprueba con la presentación de sus acciones deshonestas, y que se acerca mucho a la concepción que Héctor tiene de Paris. Por el contrario, la puesta en duda de que la apariencia del rey Lisuarte no es armónica con la valía de su persona, al decir de una doncella del libro primero: «Señor, bien se ve que sois rey en el cuerpo, mas no sé si lo seréis por el corazón» ${ }^{41}$, carece de cualquier validez porque el monarca cumple a cabalidad con la palabra empeñada.

La épica crea un ambiente propicio para descifrar significados a través de imágenes, para motivar forma y fondo como reflejos fidedignos, para hacer

${ }^{38}$ Homero describe a Tersites como el personaje más indigno de los llegados a Troya: «patizambo y cojo de una pierna; tenía ambos hombros / encorvados y contraídos sobre el pecho; y por arriba / tenía cabeza picuda, y encima una rala pelusa floreaba». Además sabía muchas «desordenadas palabras» que espetaba a los reyes de modo insultante (II, 1119). Llama la atención la maestría que demuestra Homero en el retrato de Dolón, de quien nos dice que es «de aspecto vil» y «ligero de pies», y que antes que importarle la gloria que representa espiar a los griegos como propone Héctor, se interesa rapazmente por el premio, los caballos del Pelida (X, 316-31). Por otra parte, no lleva espada, pero sí lleva arco y un «aguda jabalina», armas arrojadizas de lucha no frontal. Cuando Ulises y Diomedes lo capturan, «los dientes le castañeaban en la boca [...] / y pálido de espanto [...] se echó a llorar» (385-87).

${ }^{39}$ Homero, op. cit., III, 43-45. En el canto XXIV, Príamo con pesar afirma que no le quedan más que los hijos «baldones / mentirosos, danzarines, valiosos solo en la cadencia del coro, / depredadores de los corderos y cabritos», entre los que destaca Paris (260-62).

${ }^{40}$ Amadís de Gaula. Rosenblat, Ángel (ed). Buenos Aires: Losada, 1998, p. 135.

${ }^{41}$ Ibídem, 129. 
visible la calidad de los héroes. No resulta casual, desde este punto de vista, que el Abencerraje nos describa con tanto detalle la entrada en la novela del moro Abindarráez, el cual, según la versión de Villegas,

era grande de cuerpo y hermoso de rostro y parescía muy bien a caballo. Traía vestida una marlota carmesí y un albornoz de damasco del mismo color, todo bordado de oro y plata. Traía el brazo derecho rezagado y labrada en él una hermosa dama y en la mano una gruesa y hermosa lanza de dos hierros. Traía una darga y cimitarra, y en la cabeza una toca tunecí, que dándole muchas vueltas por ella, le servía de hermosura y defensa de su persona ${ }^{42}$.

La versión de la Diana, antes de siquiera tener algún conocimiento de la historia del moro y sustentándose únicamente en la apariencia, incluso se permite afirmar que era «tan gentil hombre y bien tallado, que su persona dava bien a entender que devía ser de gran linaje y esfuerço» ${ }^{43}$, lo que estimula la figura física hasta forzar el significado de lo meramente ornamental o anecdótico.

Cierta parte de la crítica, en el intento de asimilar al moro con las imágenes que los antiguos griegos tenían sobre los bárbaros, ha visto en la apariencia atildada de Abindarráez signos de afectación y amaneramiento ${ }^{44}$. Lo interesante es que esa misma crítica no ha pasado revista acerca del testimonio que el propio Abindarráez ofrece de sus vestidos, explicación que no deja de aparecer en el Inventario, la Chrónica y la Diana, con ligeras variantes: «púseme en el hábito en que me encontraste, el más gallardo que pude, por mejor mostrar a mi señora la ufanía y alegría de mi corazón» ${ }^{45}$. El moro, a diferencia de Narváez y los hidalgos que han salido en busca de escaramuzas, se dirige a sus bodas, debe vestirse de acuerdo con tan anhelado momento, y quiere, además, que los vestidos hablen a su dama del regocijo de la unión. La crítica así mismo tampoco ha reparado en el arrobamiento contemplativo de los cristianos, presente sobre todo en las versiones del Inventario y la Chrónica, y que estuvo a punto de provocar que los hombres de Narváez perdieran la oportunidad de obtener ganancia en la empresa nocturna, como sugiere esta última: «todo lo que hazia y dezia daua tanta gracia que los escuderos que le escuchauan | quasi como trasportados de verle y oyr- | le herraron poco de dexarle pasar» ${ }^{46}$. Por lo que se tendría que decir que si el personaje en cuestión padece de amaneramiento, los demás, hidalgos escogidos del propio Narváez que se regocijan contemplándolo, no están lejos de

${ }^{42}$ El Abencerraje, op. cit., 107-08.

${ }^{43}$ Montemayor, Jorge, op. cit., 204.

${ }^{44}$ Bollard, Kathleen, op. cit., 301; Bass, Laura R. «Homosocial Bonds and Desire in the

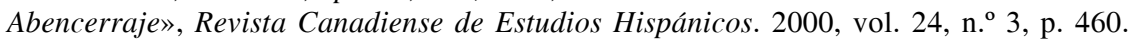

${ }^{45}$ Montemayor, Jorge, op. cit., 214; Rumeau, A., op. cit., 387; El Abencerraje, op. cit., 121 .

${ }^{46}$ Rumeau, Aristide, op. cit., 379. 
ello. De la misma manera, se ha escamoteado que a la imagen del elegante moro que va camino a sus bodas no sigue la historia de cómo es capturado sin ninguna dificultad. Por el contrario, tan magnificente descripción precede a un enconado combate que, más que resaltar que el moro finalmente es hecho prisionero, alaba y se explaya en sus cualidades bélicas, subrayando que no se desmerite lo que las obras habían imaginado con el relato minucioso de su apariencia. Abindarráez es capaz de batirse con cinco hidalgos cristianos y anular, según el Inventario y la Chrónica, a cuatro, o a tres, según la Dia$n a^{47}$, y provocar que éstos, ante la imposibilidad de la victoria, se vean en el apremio de pedir refuerzos a través de esa especie de olifante autóctono que recuerda tanto al de Oliveros. Aunque a la postre es vencido por Narváez, las diferentes versiones se encargan de señalar que la derrota del moro se debe en igual medida a la destreza del capitán español como al cansancio y las lesiones del adversario: «andavan los dos tan ligeros en el herirse y tan osados en acometerse, que si el cansancio passado y la herida que el Moro tenía no se lo estorbara, con difficultad huviera el Alcayde victoria de aquel hecho ${ }^{48}$. Tampoco se debe pasar por alto que la versión de la Diana nos informa que, entre los regalos con los que termina la obra, Jarifa incluye una «muy preciosa ropa blanca» para Narváez, con el objeto de no rezagarse en la liberalidad mostrada por su padre y su esposo ${ }^{49}$. La versión de la Chrónica va más allá cuando nos presenta al mismo capitán español regalando al alcalde de Coyn «una ropa luenga hasta en tierra : de ter- | ciopelo aceytuni carchofado / aforrada en martas ${ }^{50}$, como si se diera otra batalla que se ejecuta en los terrenos de la cortesía ${ }^{51}$. No debemos olvidar que el Poema de Mio Cid, estrictamente épico, cuyos personajes están lejos de padecer afectación, se detiene a describir los vestidos deslumbrantes que luce el protagonista cuando asiste a cortes en Toledo:

Calças de buen paño en sus camas metió,
sobr' ellas unos çapatos que a grant huebra son,
vistió camisa de rançal tan blanca como el sol,
con oro e con plata todas las presas son,
al puño bien están, ca él se lo mandó;
sobr'ella un brial primo de ciclatón
obrado es con oro, pareçen por ó son,
sobr'esto una piel vermeja las bandas d'oro son,
siempre la viste Mio Çid el Campeador;
una cofia sobre los pelos d'un escarín de pro

${ }^{47}$ El Abencerraje, op. cit., 109; Rumeau, A., op. cit., 379; Montemayor, J., op. cit., 206.

${ }^{48}$ Montemayor, Jorge, op. cit., 206.

${ }^{49}$ Ibídem, 221.

${ }^{50}$ Rumeau, Aristide., op. cit., 394.

${ }^{51}$ León, Pedro R. «Cortesía, clave del equilibrio estructural y temático en El Abencerraje», Romanische Forschungen. 1974, vol. 86, pp. 259-60. 
con oro es obrada,

de suso cubrió un manto que es de grant valor, en él abrién que ver quantos que í son ${ }^{52}$.

Desde el punto de vista que venimos analizando la historia del Abencerraje, no parece ser tan importante que la versión de Villegas sea la única que contenga el detalle de la dama labrada en la manga derecha del moro ${ }^{53}$. Los vestidos, sus colores y magnificencia, la canción que entona, la gracia de sus maneras, darían a entender claramente, además de la calidad del personaje, las intimidades de su corazón. La Diana incluso acentúa lo emocional de Abindarráez cuando afirma literalmente que el amor era para ese entonces el señor de sus pensamientos ${ }^{54}$. Lo que sí parece tener una importancia capital en el Inventario, si nos atenemos al devenir de la anécdota, es el hecho de que el capitán Narváez hiere a su enemigo precisamente en la manga donde se encuentra la imagen de su señora. El genial detalle no escaparía a la perspicacia de los lectores o espectadores contemporáneos, quienes posiblemente se predispusieran a toparse, mediante esta mínima peculiaridad, con una peripecia que colocara en riesgo la consumación del relato amoroso. Lo más probable es que constituyese una clave para imaginar cómo se desarrollaría la obra, cuál es la naturaleza de Abindarráez, y hasta incluso, sería un punto de inflexión entre lo netamente cortesano y lo netamente guerrero, aunque ninguna de las dos nociones pueda deslindarse a cabalidad de la otra.

\section{Los Mitos y EL LOGRO DE LA BELLEZA EN EL ABENCERRAJE}

No pasará mucho tiempo para que la imagen del moro que hemos presentado empiece a asociarse a narraciones mitológicas como la de Hemafrodito o la de Narciso, personajes con los que se identifica en su afán de adherirse indisolublemente a Jarifa. Algo es de destacar de estas dos historias clásicas: ninguna nos presenta una unión amorosa saludable. Sálmacis logra capturar a Hermafrodito en su laguna y, en contra de la voluntad del joven, lo obliga a fundirse con ella, de tal manera que el resultado final es una mezcla grotesca de ambos sexos, un medio hombre. Narciso consume toda la existencia contemplando su propio reflejo, el cual renacerá en la laguna Estigia de las mansiones infernales, sin que siquiera la muerte haya podido apartarlo de un deseo imposible: escindirse de su propio cuerpo para amarse. Se ha dicho que estos relatos podrían ser entendidos como una forma de develar la afectación

\footnotetext{
${ }^{52}$ Poema de Mio Cid, op. cit., 3085-3100.

${ }^{53}$ El Abencerraje, op. cit., 107.

${ }^{54}$ Montemayor, Jorge, op. cit., 205.
} 
de Abindarráez porque lo asimilan con personajes que ciertamente no se destacan por constituir dechados de virilidad. Lo curioso es que sea el moro quien estableciera dudas sobre su reputación, ya que es él mismo el que recurre a dichos relatos para explicar el propio desenfreno. Tampoco se ha puesto interés en la lectura que el personaje realiza de estos arquetipos, que, como tales, son proclives de ser interpretados de varias formas o ser rellenados de contenido según las circunstancias ya que, de acuerdo con Jung, lo que se hereda son las formas y no las representaciones en sí. En el Inventario, el moro exclama, vencido por la belleza de Jarifa: « $i O h$, quien fuera Troco para parescer ante esta hermosa diosa!» ${ }^{55}$. La versión de la Chrónica se alarga un poco para especificar cuál es la apetencia real que se esconde detrás: «O | quien fuesse Troco: para poder siempre | estar junto con esta hermosa Nimpha» ${ }^{56}$. La parte importante de la anécdota primigenia es la posibilidad de atraer a esta nueva figura femenina mediante la belleza del Troco original. Claramente, Abindarráez, en el lugar del personaje mitológico, lejos de oponerse a la propuesta erótica de Sálmacis, satisfaría todos sus deseos. Si bien, según el mito y el afán del moro, la dirección del encuentro se origina de Jarifa hacia él, en la historia de Narciso el sentido se manifiesta completamente opuesto. En todas las versiones del Abencerraje, el reflejo que el protagonista recibe de la fuente no es el de su propio talante sino el de dama: «bajando mis ojos [...] vila en las aguas de la fuente al propio como ella era, de suerte que donde quiera que volvía la cabeza, hallaba su imagen, y en mis entrañas, la más verdadera ${ }^{57}$. Este detalle hace que el tratamiento de la antigua leyenda sea mucho más psicológico que el de la de Hermafrodito. En la presente oportunidad, Abindarráez sería el llamado a aproximarse a la dama con la intención de amalgamarse con ella o con su reflejo, lo que es lo mismo, dado la confusión causada por el afuera y el adentro. Las versiones de la novela refieren a Narciso para disculpar a un personaje que pudiera anegarse en la fuente que multiplica la efigie de Jarifa, lo que en el fondo no es necesario porque se trata de una belleza interna que el protagonista no sabe cómo circunscribir y lo impele a considerar las opciones más desesperadas ${ }^{58}$. Parece algo liviano mantener que Abindarráez se concibe a sí mismo como falto de virilidad, más bien se entiende que la imagen («más verdadera») de Jarifa se proyecta desde lo interno para desbordarse desde allí, contaminando todo a su alrededor.

${ }^{55}$ El Abencerraje, op. cit., 116-117.

${ }^{56}$ Rumeau, Aristide, op. cit., 384.

${ }^{57}$ El Abencerraje, op. cit., 117.

${ }^{58}$ Quizá estemos ante una versión diferente del mito de Narciso no contenida ni en el texto original de Ovidio ni en la adaptación de Bustamante, ya que en ninguna de ellas el personaje muere ahogado. Ovidio. Metamorfosis. Álvarez, Consuelo y Rosa M. Iglesias (ed.). $8^{\mathrm{a}}$ ed. Madrid: Cátedra, 2007, p. 299. Ovidio. Las transformaciones de Ovidio en lengua española, repartidas en quinze libros, con las Allegorias al fin dellos y nus figuras, para prouecho de los Artifices. Amberes: Pedro Bellero, 1595, p. 50. 
El moro sustenta la omnipresencia de la dama entendiéndola como la belleza en su totalidad y, por el contrario, es incapaz de concebirla platónicamente, es decir, tan sólo como un elemento partícipe de la belleza. La pasión no le permite aprehender a su amada en tanto sujeto que forma parte de una idea más general y abarcadora.

A estas narraciones se une el mito del juicio de Paris, conservado en las versiones del Inventario y la Chrónica, y que la Diana sólo menciona parcialmente con la cita de Venus ${ }^{59}$. Este relato serviría para acentuar la descripción del caballero como sujeto tiranizado por el poder del amor. La referencia se da justo antes de que Jarifa aparezca coronada con la guirnalda que el moro acababa de tejer. Casalduero trató brevemente dicho pasaje para llegar a resultados semejantes a los aludidos, que los mitos clásicos actuarían en conjunto para descubrir la pasión entre los supuestos hermanos:

la escena de la corona sirve para lo mismo que la de Narciso y la de Sálmacis; es decir, para identificar con el amor el sentimiento de los hermanos, y para hacer notar la reacción de éstos al descubrirlo. Indica, además, el poder del amor y lo invencible de su fuerza; de ahí que la guirnalda de los amantes, aludiendo a la corona de los vencedores, muestre el triunfo del amor sobre los obstáculos que la interrumpían ${ }^{60}$.

Sin embargo, el investigador descuida las resonancias que un mito tan poderoso como éste trae a colación. Paris, o el hombre primigenio, tuvo que decidir qué camino tomar entre opciones tentadoras: Hera, Atenea o Afrodita. El resultado final fue, como se sabe, más que una decisión, un dejarse llevar por las pasiones, ya que Afrodita implica, en este caso en específico, exactamente una trasgresión ética: el robo de una esposa; y desde el punto de vista psicológico, la pérdida de la abstracción de belleza en tanto es pérdida de honor y de estima pública. Así también el enlace con Jarifa se eleva sobre un terreno espinoso, sobre un choque de generaciones: los jóvenes enfrentados al alcalde de Coín; y sobre una trasgresión clara, el incesto, aunque no sea verdadero finalmente. Por otra parte, la novela renacentista empieza gracias a la suposición de la posibilidad-imposibilidad de alcanzar el ideal primero, el encuentro con la amada. Desde esta perspectiva, el Abencerraje se desarrolla, al igual que la Ilíada o cualquier discurso épico, por la necesidad de reunir al hombre con la belleza (siempre perdida o proclive de ser renovada), una noción que estas dos obras particulares identifican en un principio con una mujer, Helena-Jarifa. La pequeña secuencia de la búsqueda de la belleza es la que subsiste como andamiaje a lo largo de las narraciones. Pero en cierto punto, aunque la estructura básica permanezca, el concepto de belleza empie-

${ }^{59}$ El Abencerraje, op. cit., 118; Rumeau, Aristide, op. cit., 385; Montemayor, Jorge, op. cit., 211.

${ }^{60}$ Casalduero, Jorge, op. cit., 11. 
za a difuminar sus límites más y más, hasta universalizarse y dejar de circunscribirse a un ser determinado. Es así como la Ilíada asombrosamente pierde su sentido original cuando Diomedes, recogiendo el espíritu de todos los héroes en la asamblea del canto VII, de la que pende el futuro de la guerra, responde al heraldo troyano que no aceptarán obsequios como compensación por la ofensa y que continuarán batallando aún en caso de que Helena sea devuelta: «Ni las riquezas de parte de Alejandro acepte ahora nadie / ni a Helena. Sabido es, incluso para el muy insensato, / que sobre los troyanos ya se ciernen los cabos de su perdición ${ }^{61}$. Las palabras, un tanto demagógicas del héroe, son respaldadas por los griegos, lo que nos llevaría a reformular el objeto de la guerra de Troya, no en el sentido de argüir que se realiza por algo diferente a Helena sino en el intento de re-significar a este personaje. Dado que la recuperación física en absoluto tiene lugar y que, no obstante, el poema sigue relatando las hazañas de los guerreros, no parece descabellado asimilar el significado de Helena a la conducta heroica, más cuando para la imaginación de algunos griegos, como la de Eurípides en la obra sobre el mismo personaje, la adúltera en ningún momento se trasladó a Troya.

Algo parecido ocurre en el Abencerraje, pero quizá esta obra sea incluso un poco más explícita que la de Homero. Abindarráez, a diferencia de los héroes clásicos, tiene la oportunidad de recuperar físicamente a Jarifa, sin embargo, esto, que en un principio se había planteado como lo más importante, cede terreno a un nuevo propósito o, mejor, a una revisión del cometido inicial. De hecho, hubiera sido factible, de acuerdo con la concepción de las primeras páginas, que la obra concluyera con el encuentro tan esperado entre los amantes, y que ese mundo que es una multiplicación de la hermosura de Jarifa, como nos devela Abindarráez en la escena de la fuente de los jazmines, se concretara definitivamente y para siempre. Pero a esta posibilidad se opone la premonición que la imagen física del moro permite proyectar y que echa sus bases en la palabra dada a Narváez, creando un vínculo inquebrantable entre exterior y esencia. Porque la promesa de regreso es una balanza que mide la virtud de Abindarráez; es metáfora de sí mismo y lo define a cabalidad. Es así cómo palabra e imagen se convierten en una misma cosa, y es así también cómo el moro comienza a individualizarse de Jarifa, a individualizar al mundo que le rodea, a distinguir la participación en la belleza de la belleza como concepto totalizador. Castiglione habrá sido de gran ayuda para el artífice original cuando señala que comúnmente la apariencia física es proporcional a la bondad o envilecimiento de los hombres ${ }^{62}$. Y cuando abstrae la perfección de un personaje determinado para hacerla camino hacia una noción más general, adaptando líneas como ésta de El Banquete: «la be-

\footnotetext{
${ }^{61}$ Homero, op. cit., 400-402.

${ }^{62}$ Castiglione, Baltasar de. El Cortesano. Suero Roca, Teresa (ed.). Barcelona: Bruguera, 1972, p. 429.
} 
lleza que en un cuerpo cualquiera reside es hermana de la que en otro se ha$1 l e »{ }^{63}$, y cimentando el terreno para el logro de la ascesis:

el enamorado [...] juntará en su pensamiento [...] todas las hermosuras, hará en sí un concepto universal, y reducirá la multitud [...] a la unidad [...] y así no ya la hermosura particular de una mujer, sino aquella universal, que todos los cuerpos atavia y ennoblece, contemplará; y de esta manera embebecido [...] no curará de la menor $[\ldots]$ preciará poco lo que primero había tanto preciado ${ }^{64}$.

Si antes lo que estaba en juego era el encuentro con la dama, la nueva apuesta consistirá en reunir a Abindarráez con la virtud. Para el moro no hay otra salida que el mantenimiento de su palabra, a pesar del dolor que esto inflige una vez casado con Jarifa ${ }^{65}$, y de que la separación ponga en riesgo su vida en términos pasionales: «vivir sin vos tendría por la misma muerte», como repiten la Diana y la Chrónica ${ }^{66}$. La secuencia de la acción no ha cambiado, el protagonista sigue persiguiendo un ideal, lo que ha cambiado es el objeto de ese ideal. Jarifa formará parte de él, pero no será nunca más su centro. El amor se convertirá en un subtema, como afirman Rey y Sevilla ${ }^{67}$. Abindarráez no sólo debe sustentar la honra individual, ahora descansa sobre sus hombros la honra de merecerla, lo que, sin embargo, no significa estar a su lado sino entregarse al capitán español. Por eso ante la insistencia de la recién desposada de sustituir la promesa de regreso por un cuantioso rescate, el moro sostiene firmemente:

si cuando venía a verme con vos, que iba por mí solo, estaba obligado a cumplir mi palabra, ahora, que soy vuestro, se me ha doblado la obligación. Yo volveré a Álora y me porné en las manos del alcaide de ella y, tras hacer yo lo que debo, haga él lo que quisiere ${ }^{68}$.

La propuesta de Jarifa de intercambiar prisionero por rescate, utilizando el aval económico de su padre, aunque tiene lugar en todas las versiones ${ }^{69}$, y parece ser la forma más común de saldar las cuentas de los cautivos, además de constituir una oferta tentadora, no puede equipararse al valor que tiene la honra en una cultura de vergüenza, en la que la estima pública representa lo más sagrado. Es lo que se desprende de las palabras de Diomedes citadas más

\footnotetext{
${ }^{63}$ Platón. La República o El Estado. Candel, Miguel (ed.). 25ª ed. Madrid: Espasa Calpe, 1994, p. 311.

${ }^{64}$ Castiglione, Baltasar, op. cit., 440.

${ }^{65}$ García, Dulce María. «Las funciones de la promesa en El Abencerraje», Revista de Filología Española, 2007, vol. LXXXVII, n. ${ }^{\circ}$ 1, p. 68.

${ }^{66}$ El Abencerraje, op. cit., 127; Montemayor, Jorge, op. cit., 217; Rumeau, Aristide, op. cit., 390.

${ }^{67}$ Rey Hazas, Antonio, «Contexto y punto de vista en el Abencerraje», pp. 421-422.

${ }^{68}$ El Abencerraje, op. cit., 127.

${ }^{69}$ El Abencerraje, op. cit., 127; Montemayor, Jorge, op. cit., 217; Rumeau, Aristide, op. cit., 390 .
} 
arriba, cuando, ejerciendo la vocería política de los griegos, en realidad propone un postulado ético. Es lo que además se intuye de la conducta de Aquiles del canto IX, quien, si bien obnubilado por la cólera, rechaza la justa compensación material que le propone el Atrida por el mancillamiento de su honor, esto a pesar de las palabras de Fénix y Áyax que establecen la idoneidad de resarcir ofensas con regalos ${ }^{70}$. Es lo que definitivamente propugna la Odisea cuando Ulises se niega a aceptar, en intercambio por los desafueros, la indemnización de los pretendientes propuesta por Eurímaco ${ }^{71}$. Si bien la compensación económica puede ser recibida en determinados casos, cuando se trata de la honra, no hay forma de repararla con objetos materiales. Ninguna de las composiciones del Abencerraje citadas nos ofrece a una Jarifa capaz de entender esto ${ }^{72}$. Pero, una versión tardía y quizá con propósitos exclusivamente moralizantes, La historia del moro, libre por sus propias características de casi todo el lastre emocional, presenta a una Jarifa virilizada que, además de estar dispuesta como todas a acompañar a su esposo al cautiverio, no plantea el rescate monetario como opción, aunque sí menciona las riquezas del padre. Después de que Abindarráez le explica lo que ha sucedido durante su venida, que tiene que volver a Narváez y que no quiere involucrarla para evitar su privación de libertad, esta versión informa que la mora responde:

antes de agora me has mostrado lo que me quieres y agora me lo muestras mejor pues tienes tanto respeto a mi libertad. mas pues eres tâ buen cauallero que miras lo que a mi debes y lo que debes a tu fe no plega a dios que yo este en compania de nadie sino fuese la tuya y aunque no quieras me e de ir contigo y si fueres esclauo sere esclaua y si dios te diere libertad a mi me la dara tanbien aqui

\footnotetext{
${ }^{70}$ Homero, op. cit., IX, 524-526; 632-666.

${ }^{71}$ Homero, op. cit., Odisea, XXII, 44-64. Esta es la manera más frecuente de pagar ofensas y reconciliarse en Ilíada. Hesíodo usa el mismo mecanismo en Los Trabajos y los Días: «Si un amigo comienza a ofenderte [...] acuérdate de castigarle [...]; pero, si vuelve a tu amistad y quiere ofrecerte una satisfacción, recíbela». Hesíodo. Teogonía. Los trabajos y los días. El escudo de Heracles. Villalaz, José Manuel (ed.). 6 ${ }^{a}$ ed. México, D. F.: Editorial Porrúa, 1982, p. 42. En una cultura donde no existe la noción de culpa, la idea de sufrimiento o expiación interna aún es confusa. Los hombres no se consideran artífices totales de los hechos, ni de las faltas ni de las hazañas gloriosas. Las afrentas son intercambiables por regalos. Para esto se pueden ver los siguientes pasajes de la Ilíada: III, 284-286; 456460; XVIII, 497-499; XIX, 140-145; XXII, 111-118. Es la gran idea que está detrás del canto IX. Tal vez ofrecer rescate material por los cautivos (VI, 46-50; X, 378-381; XI, 131-135; podríamos suponer que en XX, 463-469 Tros Alastórida hubiese suplicado igualmente de haberlo permitido Aquiles; XXI, 74-102; XXII, 338-352; XXIV, 112-116; 128-140; 157; 196; 503), aunque en Ilíada ya no se acepte perdonar a los suplicantes, sea una forma de ver el mismo principio: los hombres todavía no tienen conciencia de su interioridad y, por lo tanto, pueden ser canjeados por regalos. En el estadio posterior que ofrece la Odisea, con su incipiente cultura de culpa, ya no se pueden canjear presentes por ofensas graves, aunque todavía conserve vestigios: VIII, 401-411.

72 Avilés, Luis F., op. cit., 469.
} 
tengo este cofre con dinero y joyas tomame a las ancas de tu caballo que yo soy muy contenta ${ }^{73}$.

Es una Jarifa cortada, sin duda, a la medida de lo dogmático. Incluso choca por su simplicidad, que por momentos parece asimilarse más a un ideal ético abstracto que a un personaje de carne y hueso. Sin embargo, sirve de manera más expedita que las otras a los propósitos heroicos precisamente por no recurrir al subterfugio del rescate, por no intentar la ecuación fallida de equiparar honra con materia económica, por estimular más en Abindarráez el énfasis en sus deberes como caballero que como amante.

La versión del Inventario, la única que nos presenta un episodio de la juventud de Narváez, vuelve a imaginar al personaje de Jarifa cargado de esa emocionalidad que, ante la posible separación, recurrió a la vía del rescate material como sustituto de la honra. Villegas pone en boca del viejo que los amantes topan camino a Álora, lugar donde se entregarán al capitán español, una breve historia que relata cómo Narváez ardía en deseos por una dama casada. En un principio, las proposiciones deshonestas no hicieron mella en el carácter de la mujer, pero su inclinación cambia radicalmente cuando escucha al marido encumbrar a Narváez por cualidades más que todo militares. Decide, amparada en la afición que los propios hombres sienten por él, aceptar las aproximaciones eróticas de tan excelente caballero. Irónicamente el efímero enlace que cuenta con una entrevista a solas $^{74}$ se ve cercenado cuando la dama le confiesa por qué ha convenido a acceder a sus ruegos ${ }^{75}$. Narváez desiste del empeño al verse interpelado por la propia imagen idealizada que el marido refiere a través de la esposa, al notar el abismo entre actos presentes y reverberación pública pasada. No creemos que se trate tan sólo de un desprendimiento caritativo para con el deshonrado, como afirma Glenn ${ }^{76}$. Se produce un choque, un efecto de discontinuidad; los posibles resultados de la circunstancia actual provocarían un alejamiento de la imagen de belleza de Narváez, incluso alabada por otros hombres. El caballero advierte que para recuperar la propia identidad, para retomar el camino hacia ella, debe contener sus inclinaciones sexuales, sinécdoque de lo emocional que desvía de la

${ }^{73}$ Dale, George Irving. «An Unpublished Version of the Historia de Abindarraez y Jarifa», Modern Languages Notes. 1924, vol. 39, n. ${ }^{\circ} 1$, pp. 31-32

${ }^{74}$ Este encuentro furtivo se describe de la siguiente manera: la dama «le rescibió dulcemente y le metió en su cámara, donde pasaron muy dulces palabras». El Abencerraje, op. cit., 130. Casi la misma fórmula es usada para narrar la unión de Jarifa y Abindarráez: «se acostaron en su cama [...] pasaron muy amorosas obras y palabras». El Abencerraje, op. cit., 125. La ausencia de 'obras' en el relato de Rodrigo quizá daría a entender que no se consumó el acto sexual, pero la ofensa al marido es clara, aunque Bass la niegue. BASS, Laura, op. cit., 457.

${ }^{75}$ García, Dulce, op. cit., 72.

${ }^{76}$ Glenn, Richard F. «The Moral Implications of El Abencerraje», Modern Languages Notes, 1965, vol. 80, n. ${ }^{\text {2 }}$, p. 208. 
ascesis, como no olvida mencionar Villegas por boca del viejo narrador: «el caballero a mi parescer usó de gran virtud y valentía, pues venció su misma voluntad». La evaluación de Jarifa de la parábola, por el contrario, desconoce la ponderación que los héroes hacen entre una imagen totalizadora de belleza, a la cual se sienten pronosticados en la búsqueda del ideal, y una belleza específica que sólo conduce al goce efímero de lo físico: «Por Dios, señor, yo no quisiera servidor tan virtuoso, mas él debía estar poco enamorado, pues tan presto salió afuera y pudo más con él la honra del marido que la hermosura de la mujer» ${ }^{77}$. Estas palabras desenfadadas, referidas por el autor como «graciosas», son reflejo de la actuación precedente de Jarifa, y en específico, de la propuesta de intercambiar objetos materiales por la promesa de regreso. Mientras el moro y Narváez sienten como imperativo la consecución constante de nuevas hazañas, ya físicas ya psicológicas, Jarifa privilegia siempre lo emocional sobre lo heroico ${ }^{78}$.

La épica ya había hecho un lugar común del cercenamiento de los lazos eróticos que impedían al héroe cumplir con sus responsabilidades morales. El ejemplo más perfecto quizá se encuentre en la despedida entre Héctor y Andrómaca del canto VI de la Ilíada ${ }^{79}$, repercusión de lo que los griegos por su parte han dejado atrás, más si agregamos los mitos del famoso sacrificio de Ifigenia, ejecutada por su padre Agamenón con el objeto de propiciar a los dioses y lograr vientos oportunos que condujeran a Troya. Por segunda vez los caballeros, llámense Narváez o Abindarráez, no importa, son expuestos a la misma prueba: decidir entre una vida burguesa y la vida del esfuerzo, entre la sensualidad y el deber, entre la intrascendencia y la trascendencia, porque a fin de cuentas lo que está en juego es la inmortalidad que otorga la fama. Se trata del mismo dilema de Paris en el principio de los tiempos que se renueva y se camufla de anécdota renacentista. Es el paradigmático vencerse a sí mismo que siempre propone el género épico y que se enmascara como contención sexual, como rompimiento de vínculos familiares o amorosos, como entrega a la muerte en la batalla, como equivalencia entre palabra y hecho. Es un sacrificio que finalmente siempre involucra la dominación del propio carácter, algo que explícitamente propone Fénix en el canto IX cuando exhorta a Aquiles a deponer la cólera que tanto daño hace al bando griego. Y que recuerda el aforismo de Heráclito: «el carácter es para un hombre su destino», que humaniza las fuerzas sobrenaturales o demoniza las actuaciones humanas, que, en todo caso, desvía la atención sobre las potencias divinas y las centra en el hombre.

\footnotetext{
77 El Abencerraje, op. cit., 130-1f31

${ }^{78}$ Hernández-Pecoraro, Rosile. «Jarifa's Choice: A Gendered Reading of El Abencerraje y la hermosa Jarifa», Bulletin of Spanish Studies, 2002, vol. LXXIX, p. 441.

${ }^{79}$ Homero, op. cit., 392-493
} 


\section{Lo RELIGIOSO EN EL ABENCERRAJE}

La conexión del Abencerraje con los discursos épicos y mitológicos clásicos no se limita exclusivamente a la noción de héroe y sus características, como hemos analizado. También incluye algo de la mecánica cosmológica de los antiguos griegos disfrazada de cristianismo. De alguna manera, el Abencerraje se las arregla para dejar de lado la religión, aunque ésta juegue un papel importante en la definición básica de todos los personajes y en el meollo de la historia. Apenas las menciones a Dios o Alá pueden ser tomadas en serio y no como meras expresiones vacías de significado ${ }^{80}$. Pero no ocurre lo mismo con lo religioso, con ese aparato de fuerzas desconocidas que se yergue sobre los hombres y sirve para explicar el curso de los acontecimientos, y que la obra da en llamar fortuna, suerte, ventura o, incluso, amor. Por supuesto que los personajes también recurren a estas palabras con el objeto de explicar situaciones indescifrables, y muchas veces de ello resultan frases hechas sin mayor relevancia $^{81}$. Lo interesante es que, además de alterar la situación terrenal, elevar hasta su máxima capacidad o estrellar contra la tierra, este panteón indefinido siente celos de los mortales. El asunto de la envidia divina o phthonos, que quizá pase un tanto inadvertido para la cristiandad, era determinante para los antiguos griegos, quienes lo concibieron como una especie de mecánica cosmológica que actuaba cuando el hombre perdía la comprensión de su naturaleza mortal estimándose más allá de sus límites. Los dioses se manifestaban para hacerle comprender que no podía invadir las prerrogativas divinas ${ }^{82}$. Era una función bastante profiláctica, cuyo fin imponía la comprensión de la ley terrena: todo lo humano está unido indefectiblemente a la caída, al cambio, a la muerte. No se trataba de entender que los hombres se creían dioses sino que olvidaban sus propios límites en ciertas ocasiones y era necesario bajarlos de su infatuación (hybris) y hacerlos entrar en su justa medida humana ${ }^{83}$. Las divinidades se ase-

${ }^{80}$ La versión del Inventario menciona 'Dios' en dos ocasiones, paradójicamente una de ellas se pone en boca de Jarifa, misma cantidad cuenta para 'ley'. El Abencerraje, op. cit., 128, 130, 105, 135. La Chrónica presenta 'Dios' una vez y dos veces 'ley'. Rumeau, Aristide, op. cit., 391, 377, 394. La Diana refiere una vez 'fe cristiana' y 'ley', y es la única que incluye 'Alá'. Montemayor, Jorge, op. cit., 204, 221, 209, 210.

${ }^{81}$ La palabra 'fortuna' aparece nueve veces en el Inventario; 'ventura', dos veces; y los vocablos 'cielo' y 'suerte' son tratados una vez como lo mismo. El Abencerraje, op. cit., 111, 112, 112, 114, 115, 118, 119, 122, 132; 121, 123; 122. La Chrónica presenta diez veces la palabra 'fortuna'; una vez 'ventura'; y tres veces 'suerte'. Rumeau, Aristide, op. cit., 378, 381, 382, 382, 383, 385, 386, 387, 391, 392; 381; 386, 387, 387. La Diana también incluye diez veces la palabra 'fortuna'; 'ventura' sólo es mencionada una vez así como 'suerte'. Montemayor, Jorge, op. cit., 206, 206, 206, 207, 207, 208, 210, 214, 218, 219; 213; 214.

${ }^{82}$ Dodds, E.R., op. cit., 40.

${ }^{83}$ Hay muchas manifestaciones de concebirse una deidad o, al menos, más allá de lo humano: caminar por la alfombra de los dioses (Agamenón), creer que se puede dominar la 
guraban de que el hombre no pisara espacios que no le correspondían, ni se apropiara de facultades que no le estaban reservadas. Una cultura de vergüenza como la de la Ilíada, donde los héroes incluso acceden a combatir contra las propias divinidades en batalla campal, no está muy interesada en advertir los peligros de la envidia de los dioses, aunque sí la mencione en varias ocasiones ${ }^{84}$. La Odisea, sin embargo, da muestras más fehacientes de la actuación del phthonos en el ámbito humano ${ }^{85}$, esto en el entendimiento programático que la misma obra expone desde los primeros versos, los cuales establecen que los mortales pagarán por sus propios pecados y ya no podrán inculpar a los dioses ${ }^{86}$.

Las versiones del Inventario, la Diana y la Chrónica son herederas de esta noción de higiene divina y la mencionan puntualmente en tres momentos ${ }^{87}$. Quienesquiera que hayan sido los autores debieron entender dicho aspecto religioso como crucial para la historia, ya que ninguno de ellos deja pasar el detalle como insignificante o falto de interés. Las situaciones en las que se presenta siempre están relacionadas con un exceso de bienestar que súbitamente es apartado de los hombres. La primera ocasión tiene que ver con la familia de los Abencerrajes, de la cual la Diana dice que «vino la fortuna embidiosa del descanso y contentamiento de los hombres, a deriballos de aquel estado, en el más triste y desdichado que se puede ymaginar ${ }^{88}$. La segunda mención ocurre cuando Jarifa y Abindarráez se ven en peligro de ser separados para siempre debido a que el padre de la primera es ascendido a alcalde de Coín por el rey de Granada, obligando a la mora a dejar Cártama y frustrando la felicidad y cercanía idílica de los falsos hermanos ${ }^{89}$. La tercera es referida por el propio moro, quien, ante la perplejidad de la derrota contra Narváez y los escuderos, achacada en un principio a razones físicas, y ante

naturaleza a voluntad (Jerjes), solucionar la plaga (Edipo), tener varias vidas (Admeto). Cada tragedia da una versión nueva de cómo los hombres traspasan sus límites: no aceptan la posibilidad de caer en desgracia o de salir de ella (Filoctetes, Ion), es decir, no entienden que son mortales y que están sujetos a la contingencia. Vermeule, a lo largo del capítulo IV de La Muerte en la Poesía y en el Arte de Grecia, da ejemplos de cómo podía tratar de usurparse la inmortalidad: comida de los dioses (Tántalo), violación de alguna deidad (Ixión), burlar la muerte a través de un vocabulario experto (Sísifo). Vermeule, Emily. La Muerte en la Poesía y en el Arte de Grecia. Melena, José L. (trad.). México D.F.: Fondo de Cultura Económica, 1984.

${ }^{84}$ Ver Homero, op. cit., VII, 446-53; XII, 3-19.

${ }^{85}$ Ibídem, Odisea, IV, 181; V, 118; VIII, 565-69; XIII, 129-64; XXIII, 211.

${ }^{86}$ Ibídem, I, 32-43.

${ }^{87}$ Incluso La historia del moro, a pesar de su cortedad y estilo esquemático, también parece esconder el phthonos detrás de las vicisitudes humanas: «quiso mi mala fortuna que me tomasen captiuo tus cauallos y perdiese mi libertad y todo el bien y buena uentura que pensaba tener». Dale, George, op. cit., 32.

${ }^{88}$ Montemayor, Jorge, op. cit., 208; El Abencerraje, op. cit., 114; Rumeau, Aristide, op. cit., 382 .

${ }^{89}$ El Abencerraje, op. cit., 119; Montemayor, Jorge, op. cit., 213; Rumeau, Aristide, op. cit., 386. 
la pérdida repentina de la alegría de sus bodas, exclama: «no creyera yo que bastaran cient caballeros juntos a tenerme campo porque traía mi señora conmigo, y si tú me venciste, no fue por esfuerzo, que no es posible, sino porque mi corta suerte o la determinación del cielo quisieron atajarme tanto bien ${ }^{90}$. Además de estas menciones a unas potencias desconocidas que escamotean la permanencia en el bienestar, obligando a Abindarráez a persistir en un estado de sujeción, todas las versiones coinciden en agregar una más. Es de esta manera que el amor emerge al mismo tiempo que como opresor de los sentimientos, fuente de enfermedad y locura, también como dios capaz de establecer claros límites entre el hombre y la felicidad. El moro apunta a ello cuando se devela el inexistente parentesco fraternal entre la pareja:

el amor por vengarse de nosotros nos descubrió la cautela, que, como fuimos creciendo en edad, ambos acabamos de entender que no éramos hermanos. Ella no sé lo que sintió al principio de saberlo, mas yo nunca mayor contentamiento recebí, aunque después acá lo he pagado ${ }^{91}$.

Si bien es cierto que las versiones mediante el concepto de la envidia de los dioses parecen negar que los hombres puedan acceder a estados interminables de exultación, no es menos cierto que ninguna de ellas olvida mencionar cómo se logra la felicidad que es propia de los mortales. Por supuesto, el único capaz de descifrar el misterio y transmitirlo es Narváez, así como el único capaz de entenderlo a cabalidad es el moro. La fórmula del capitán español para combatir los embates del destino es en el fondo sencilla, pero de ejecución trascendente y difícil. Se trata del ejercicio constante de oponer la virtud a la fortuna, como han notado Glenn y Casalduero ${ }^{92}$ : «Abindarráez, quiero que veas que puede más mi virtud que tu ruin fortuna. Si tú me prometes [...] volver [...] yo te daré libertad ${ }^{93}$. El tono de la obra cambia totalmente después de estas palabras, pues lo que parecía una historia de amor fallida, se convierte en una búsqueda decididamente ética. Y aunque las mismas palabras de Narváez contengan la respuesta al acertijo de lo que debe hacer el moro en este caso específico, el apotegma es universal, una forma de vida, que se adapta a cualquier situación, que traspasa geografías, épocas y géneros para equipararse con el vencerse a sí mismo, característico de los discursos heroicos. Esta vez, claro, la fórmula tiene la tendencia de contrarrestar los altibajos de la vida y conseguir la liberación defini-

${ }^{90}$ El Abencerraje, op. cit., 122; Montemayor, Jorge, op. cit., 214; Rumeau, Aristide, op. cit., 385. La afirmación recuerda, aunque sea retóricamente, que los grandes héroes como Patroclo (XVI, 791), Héctor (XXII, 299) o Aquiles (XXII, 359) no pueden ser vencidos sin la intervención divina.

${ }^{91}$ El Abencerraje, op. cit., 118; Montemayor, Jorge, op. cit., 211; Rumeau, Aristide, op. cit., 385 .

${ }_{92}$ Glenn, Richard, op. cit., 207; Casalduero, Jorge, op. cit., 14-15.

${ }^{93}$ El Abencerraje, op. cit., 122; Montemayor, Jorge, op. cit., 214; Rumeau, Aristide, op. cit., 387. 
tiva de esas fuerzas opresoras. En la medida en que el hombre actúe virtuosamente, la fortuna o cualquier otra potencia podrá modificar las circunstancias en las que se ve involucrado, pero nunca su conducta. De allí, la verdadera liberación final. Los mortales continuarán sufriendo los vaivenes de la existencia pero sin estar sujetos a ellos, su actuación no dependerá del entorno, sino de una comprometida línea ética que no busca pasajeros bienes sensuales sino la bondad universal.

\section{CONCLUSIÓN}

No cabe duda, después de lo que hemos analizado, de que el autor del Abencerraje conocía muy bien las narraciones clásicas y que las tuvo presentes en la composición de su obra, lo que hizo no sólo desde un punto de vista anecdótico sino desde un punto de vista profundo del significado. Se trata de un autor sumamente culto, capaz de fundir diferentes tradiciones y adaptarlas a una historia particular sin perder de vista la trascendencia de su trabajo. La deuda del Abencerraje con la épica es notable y parecería inapropiado tratar su materia sin tener en cuenta tanto el género en sí como ejemplos clásicos griegos. Por otra parte, la maestría con la que el autor supo combinar mitos y cantos homéricos, y sacar la médula de ellos en una novela que difícilmente alcanza las treinta páginas es sencillamente digna de admiración. De hecho, la contienda psicológica, el crecimiento interno del personaje de Abindarráez, la búsqueda de la belleza platónica y su mantenimiento, son a cabalidad un homenaje a los grandes discursos clásicos, una condensación del ideal caballeresco, un antídoto contra el olvido.

\section{BIBLIOGRAFÍA CITADA}

Amadís de Gaula. Rosenblat, Ángel, ed. (1998). Buenos Aires: Losada, 447 pp.

Avilés, Luis F. (2003). «Los suspiros del Abencerraje», Hispanic Review. Vol. 71, n. ${ }^{\circ}$ 4, pp. 453-472.

Bass, Laura R. (2000). «Homosocial Bonds and Desire in the Abencerraje», Revista Canadiense de Estudios Hispánicos. Vol. 24, n. ${ }^{\circ} 3$, pp. 453-472.

Bataillon, Marcel (1964). Varia lección de clásicos españoles, José Pérez Riesco (trad.). Madrid: Gredos, 443 pp.

Bollard, Kathleen (2003). «Re-reading heroism in El Abencerraje», Bulletin of Spanish Studies. Vol. LXXX, n. ${ }^{\circ}$ 3, pp. 297-307.

Burshatin, Israel (1984). «Power, Discourse, and Metaphor in the Abencerraje», Modern Languages Notes. Vol. 99, n. ${ }^{\circ}$ 2, pp. 195-213.

Casalduero, Joaquín Gimeno (1972). «El Abencerraje y la hermosa Jarifa: composición y significado», Nueva Revista de Filología Hispánica. Vol. XXI, n. ${ }^{\circ}$ 1, pp. 1-22.

Castiglione, Baltasar de (1972). El Cortesano, Teresa Suero Roca (ed.). Barcelona: Bruguera, 1972. $446 \mathrm{pp}$. 
Dale, George Irving (1924). «An Unpublished Version of the Historia de Abindarraez y Jarifa», Modern Languages Notesvol. Vol. 39, n. ${ }^{\circ} 1$, pp. 31-33.

Deferrari, Harry A (1927). «Trocho in El Abencerraje», Modern Languages Notes. Vol. 42, n. ${ }^{\circ} 8$, pp. 529-530.

Dodds, E. R (1989). Los griegos y lo irracional, María Araujo (trad.). Madrid: Alianza, 292 pp.

El Abencerraje (Novela y romancero) (1980). Francisco López Estrada (ed.). Madrid: Cátedra, 1980. 205 pp.

Esquilo (1976). Las siete tragedias, Ángel Garibay, Ángel (ed.). 12a ed. México, D. F.: Editorial Porrúa, 171 pp.

Eurípides (2000). Las diecinueve tragedias. Ángel Garibay (ed.). 19ª ed. México, D. F.: Editorial Porrúa, 533 pp.

Fosalba, Eugenia (2002). «Sobre la verdad de los Abencerrajes», Boletín de la Real Academia de Buenas Letras de Barcelona. Vol. 48, pp. 313-334.

García, Dulce María. (2007) «Las funciones de la promesa en El Abencerraje», Revista de Filología Española. Vol. LXXXVII, n. ${ }^{\circ}$ 1, pp. 45-78.

Glenn, Richard F (1965). «The Moral Implications of El Abencerraje», Modern Languages Notes. Vol. 80, n. ${ }^{\circ}$ 2, pp. 202-209.

Hernández-Pecoraro, Rosile (2002). «Jarifa's Choice: A Gendered Reading of El Abencerraje y la hermosa Jarifa», Bulletin of Spanish Studies. Vol. LXXIX, pp. 429-446.

Heródoto (1999). Los nueve libros de la historia. María Rosa Lida de Malkiel (ed.). Barcelona: Océano, $561 \mathrm{pp}$.

Hesíodo (1982). Teogonía. Los trabajos y los días. El escudo de Heracles. José Manuel Villalaz (ed.). $6^{\text {a }}$ ed. México, D. F.: Editorial Porrúa, 83 pp.

Homero (1999). Ilíada Odisea. Carlos García Gual (ed.); Emilio Crespo Güemes y José Manuel Pabón (trad.). Madrid: Espasa Calpe, 1999. 1766 pp.

Krauel, Ricardo (1996). «El esquema heroico de la historia de Abindarráez», Romance Notes. Vol. 37, n. ${ }^{\circ} 1$, pp. 39-47.

León, Pedro R (1974). «Cortesía, clave del equilibrio estructural y temático en El Abencerraje», Romanische Forschungen. Vol. 86, pp. 255-264.

López Estrada, Francisco (19180). «Introducción», en El Abencerraje (Novela y romancero). Madrid: Cátedra, pp. 11-100.

Montemayor, Jorge de (1954). Los siete libros de la Diana, Francisco López Estrada (ed.). $2^{\mathrm{a}}$ ed. Madrid: Espasa Calpe, $302 \mathrm{pp}$.

Ovidio (2007). Metamorfosis Consuelo Álvarez y Rosa M. Iglesias (ed.). $8^{\mathrm{a}}$ ed. Madrid: Cátedra, $824 \mathrm{pp}$.

Ovidio (1595).Las transformaciones de Ovidio en lengua española, repartidas en qvinze libros, con las Allegorias al fin dellos y nus figuras, para prouecho de los Artifices. Amberes: Pedro Bellero, 242 pp.

Platón (1994). La República o El Estado, Miguel Candel (ed.). 25ª ed. Madrid: Espasa Calpe, $442 \mathrm{pp}$.

Platón (1959). Diálogos Socráticos, Ángel Vassallo (ed.). $5^{\text {a }}$ ed. Buenos Aires: W. M Jackson, 1959. 379 pp.

Poema de Mio Cid (2002). Eukene Lacarra Lanz (ed.). Barcelona: Área, 273 pp.

Rey Hazas, Antonio y Florencio Sevilla Arroyo (1987). «Contexto y punto de vista en el Abencerraje», Dicenda. Vol. 6, pp. 419-428.

Rumeau, Aristide (1957). «L'Abencérage. Un texte retrouvé», Bulletin Hispanique. Vol. 59, pp. 369-395.

Sófocles. Las siete tragedias (1976). Ángel Garibay (ed.), 13ª ed. México, D.F.: Editorial Porrúa, $221 \mathrm{pp}$. 
Torres Corominas, Eduardo (2006). «Antonio de Villegas y Jerónimo de Millis: acuerdos y desacuerdos en torno a la segunda edición del Inventario», Revista de Filología Española. Vol. LXXXVI, pp. 413-434.

Vermeule, Emily (1984). La Muerte en la Poesía y en el Arte de Grecia, José L. Melena (trad.). México D.F.: Fondo de Cultura Económica, 363 pp.

Villegas, Antonio de (1955). Inventario. Madrid: Colección Joyas bibliográficas, 13, 163 pp.

Fecha de recepción: 14 de diciembre de 2009

Fecha de aceptación: 16 de julio de 2010 